\title{
THE POLITICS OF MULTICULTURALISM AS REPARATION FOR WESTERN COLONIALISM: \\ A CRITICAL APPROACH ON MODERNITY'S NORMATIVE PARADIGM
}

Política do multiculturalismo como reparação pelo colonialismo ocidental: uma
recolocação do paradigma normativo da modernidade Leno Francisco Danner *

Abstract: This study starts from a criticism against the naturalization and depoliticization of the normative paradigm of modernity. Such criticism was made by some contemporary philosophical-sociological theories that associated modernity directly with universalism and conceived it as the final stage of human evolution (in terms of epistemological-moral consciousness, culture and material organization), as opposed to traditionalism. The article argues that modernity is not a universalistic epistemological-moral paradigm or a material and societal organization from which multiculturalism can be embraced, promoted and guided, particularly in the international context. Consequently, I reject the direct association, proposed by such philosophical-sociological theories, of universalism, cosmopolitanism and globalization with the epistemological, cultural and economic modernization. In other words, universalism does not mean modernization, as it does not justify the totalizing pursuit of modernity as a paradigm and a material-institutional form of life for all contexts and as a condition for their stability. I therefore propose a reformulation of the paradigm of modernity with the concept of Western colonialism reparation, which must start from the recognition of the historical-sociological blindness concerning the intrinsic link between the normativity of modernity and the Realpolitik of modern colonialism. Such blindness implies the statement that modernity is inherently self-reflexive, justifying it as the basic paradigm for the context of modernity as well as for

* Doutor em Filosofia (PUC-RS). Professor de filosofia e de sociologia no Departamento de Filosofia da Universidade Federal de Rondônia (UNIR). Artigo recebido em 19/03/2018 e aprovado para publicação em 11/02/2019. 
the sphere of international politics. This would reinforce its permanence as a universalistic paradigm and cosmopolitan ethical-political project. Based on that separation, modernity can always function as the starting point and as the point of arrival to universalism, transforming modernization into universalism itself.

Key-words: Modernization, Multiculturalism, Politics, Colonization, Duty of Reparation.

Resumo: partindo de uma crítica à naturalização e à despolitização do paradigma normativo da modernidade, por teorias filosófico-sociológicas contemporâneas, que associam-na diretamente ao universalismo e concebem-na como o estágio final da evolução humana (em termos de consciência epistemológico-moral, de cultura e de organização material), contrariamente ao tradicionalismo, eu argumento que a modernidade não é um paradigma epistemológico-moral universalista e nem uma organização societal material a partir dos quais o multiculturalismo pode ser reunido, promovido e guiado, particularmente no que se refere ao contexto internacional. Como consequência, eu nego a associação direta, por tais teorias filosófico-sociológicas, entre universalismo, cosmopolitismo e globalização com a modernização epistemológica, cultural e econômica. Em outros termos, universalismo não significa modernização, da mesma forma como ele não justifica a prossecução totalizante da modernidade como paradigma e forma de vida material-institucional para todos os contextos e como condição da estabilidade destes. Com o conceito de reparação pelo colonialismo ocidental, eu proponho uma reformulação do paradigma da modernidade que começa com o reconhecimento da cegueira histórico-sociológica no que diz respeito à ligação intrínseca entre a normatividade moderna e a Realpolitik do colonialismo moderno, cegueira esta que implica na afirmação de que a modernidade é autorreflexiva desde dentro, justificando-a como o paradigm básico tanto para o contexto da modernidade quanto para a esfera política internacional. Como consequência, ela pode continuar enquanto paradigma universal e projeto ético-político cosmopolita. Baseada naquela separação, a modernidade pode sempre servir como ponto de partida e como ponto de chegada ao universalismo, de modo que a modernização transforma-se no próprio universalismo.

Palavras-chave: Modernização, Multiculturalismo, Política, Colonialismo,;///// Dever de Reparação.

\title{
Introduction
}

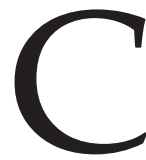

ontemporary ethical-political theories take the fact of multiculturalism as their epistemological-political starting point. Multiculturalism points to the end of the metaphysical-theological foundations regarding the constitution, legitimation and evolution of modern societies. ${ }^{1}$ Of course, modern societies are not necessarily atheis-
\end{abstract}

\footnotetext{
${ }^{1}$ See RAWLS, John. O Liberalismo político. Brasília: Instituto Teotônio Vilela; São Paulo: Editora Ática, 2002; HABERMAS, Jürgen. Pensamento pós-metafísico: estudos filosóficos. Rio de Janeiro:
} 
tic or completely secular ones-in fact, contemporary societies, even if they are based on secularism, individualism and scientism, do not have a purely rational life and structuration, in the sense that many of their citizens and communities are religious, living and grounding their lives on religious ways and senses. However, such related and concomitant conditions of pluralism and individualism lead to skepticism regarding the metaphysical-theological foundations as the normative basis of political institutions and social life at large. Here, the democratic modern alternative to the naturalized and essentialist foundations is the endless and tense intersubjective debate between free and equal citizens and social-cultural groups concerning what they consider the best social path, the best socially binding norms and practices and the best political institutional structuration as well. Thus, when modern societies are mentioned, it is the European model of socialization based on secularism, pluralism, individualism and democracy that is being referred to as the alternative to essentialist and naturalized foundations that depend on a metaphysical-theological grounding. In philosophical-sociological reconstructions of the normative and empirical contents of modernity (such as classical sociology and, more recently, the theories of Rawls, Habermas, Giddens and Honneth), modern European culture is the counterpoint of traditionalism; and human evolution from modernization is only possible through more modernization, so that a return to traditionalism is not possible in modern societies - this is the self-understanding of modern societies and modern culture. ${ }^{2}$

For a long time, such model of modernization was considered as totally capable of facing the challenges of social integration and of the collective-individual sense of modern societies. Democratic modern societies, from the second half of the $20^{\text {th }}$ century, have developed increasingly strong institutions, policies, rights and a public culture that performed an exemplary social integration with the consistent political participation of all citizens and cultural groups, both native and foreigner. Such successful processes of social-political inclusion in modern societies enabled the use of modernization as a universalistic normative paradigm from which a critical social theory and a democratic political praxis could be built as criticism and transformation of current times-that is the case of Jürgen Habermas' theory of modernity, which begins from a reconstruction of an idealized model of European modern culture as allowing a universalistic epistemological-moral paradigm to criticize, integrate and intervene not only in the context of modern societies, but

Tempo Brasileiro, 1990a; HONNETH, Axel. Luta por reconhecimento: a gramática moral dos conflitos sociais. São Paulo: Editora 34, 2003.

2 See HABERMAS, Jürgen. O discurso filosófico da modernidade: doze lições. São Paulo: Martins Fontes, 2002a, p. 122. 
in the international context as well. ${ }^{3}$ Then, modern culture generates and consolidates a decentralized conscience that can think and act only by formalist principles and in a non-egoistic and non-ethnocentric way, which means that modern European culture, as the apex of human evolution in relation to traditionalism, becomes the universalistic platform to criticize, integrate and intervene in all contexts, exactly because of the fact that it is sensible to differences. ${ }^{4}$

However, the beginnings of the $21^{\text {st }}$ century have deconstructed much of that normative comprehension based on European cultural universalism as the fundamental groundwork for an ethical-political project of criticism, integration and intervention. Indeed, a set of national and international problems caused by cultural-economic modernization have strongly delegitimized modernity's self-comprehension in relation to its universalistic role and range, namely: (a) the ideological-political use of the modern epistemological-moral paradigm by contemporary colonialism (for example, the invasion of Afghanistan and Iraq by USA and by a coalition of European countries as well as their intervention in Libya and Syria and also the current crisis between NATO and Russia in Ukraine); (b) the growth of unemployment and social inequalities in developed societies which leads to a situation of marginalization, exclusion and poverty, having as its consequence the increase of suffering and violence in these societies; (c) a global social-economic crisis leading to the weakening of the Welfare State, public policies and social rights, which are the normative-political basis of modern developed societies, becoming a normative-political model also to developing societies (as Brazil and other Latin-American countries); (d) an economic globalization characterized by the absolute supremacy of financial capital and of the destabilization of national economies and work regimes, which means the victory of supranational companies and, here, of underpaid jobs; (d) the intensification of migratory crisis and of many kinds of chauvinism and cultural-political conservatism in modern democracies; and (e) a very accelerated ecological crisis caused by the unstoppable industrialism and consumerism which constitute the social-economic basis to the development of current capitalism. ${ }^{5}$ Such problems lead us to ask

\footnotetext{
${ }^{3}$ See HABERMAS, Jürgen. O discurso filosófico da modernidade; Idem, HABERMAS, Jürgen. $O$ ocidente dividido. Rio de Janeiro: Tempo Brasileiro, 2006.

${ }^{4}$ See HABERMAS, Jürgen. La Constelación posnacional: ensayos políticos. Barcelona: Ediciones Paidós, 2000, p. 9-10; HABERMAS, Jürgen. A inclusão do outro: estudos de teoria política. São Paulo: Loyola, 2002b, p. 7.

${ }^{5}$ See BENAYON, Adriano. Globalização versus desenvolvimento. Brasília: LGE, 1998; PIKETTY, Thomas. O capital no século XXI. Rio de Janeiro: Intrínseca, 2014; BOLTANSKI, Luc \& CHIAPELLO, Ève. O novo espírito do capitalismo. São Paulo: Martins Fontes, 2009; HABERMAS, Jürgen. Europe: the faltering project. Cambridge: Polity Press, 2009; HONNETH, Axel \& HARTMANN, Martin, "Paradojas del capitalismo", In: HONNETH, Axel. Crítica del agravio moral: patologías de la sociedad contemporánea. Buenos Aires: Fondo de Cultura Económica, 2009, p. 389-422; OFFE, Claus. Problemas estruturais do Estado capitalista. Rio de Janeiro:
} 
whether modernity's universalism can effectively sustain a critical social theory and a democratic political praxis to enable the resolution of those problems and, therefore, the construction of a fair, peaceful and ecological world of free and equal individuals, communities and societies. And, if the answer to this question is positive, how is it possible nowadays?

In this article, I will argue that such problems are caused by a totalizing process of cultural-economic modernization which has linked all peoples and countries in a very intrinsic and explosive political-economic relationship basically streamlined by the model of monopolist capitalism and of liberal politics centralized and monopolized in USA and NATO-which is truly the heritage of colonialism and the situation in current colonialism, that is, the imposition of Western liberal capitalism to all societies as the paradigmatic model of social evolution. Such a model of capitalism and liberal politics fostered by the United States of America and NATO has two imbricated pathways, namely: (a) the direct imposition of monopolist capitalism and liberal politics to all contexts as the only evolutionary route to development; and (b) the violent opposition to and delegitimization of adversarial societies that can offer a political-economic project alternative to the model of liberal capitalism. This is the epistemological-political starting point to rethink the critical social theory's normative foundations and to ground an emancipatory democratic political praxis based on the universalism of modernity. Now, that epistemological-political starting point leads to a new approach of the path and sense of modernity. In other words, if modern universalism was generally used by contemporary philosophical-political theories to support the pursuit of modernity as a universalistic epistemological-political paradigm and global project, in a direct attack against traditionalism, today modern universalism can only survive as the normative basis to a critical social theory and to a democratic political praxis if its intention is to restrain and limit modernity's cultural-economic movement towards globalization. Indeed, here emerges modernity's contemporary aim and future: the reparation for Western colonialism. This implies a work of deconstruction and delegitimization of the liberal self-comprehension of Western cultural-economic modernization as the apex of human evolution and its association between Western cultural-economic modernization and universalism. The reparation for Western colonialism implies not only internal criticism, restraining and limitation of cultural-economic modernization, but also the reconstruction of the global order from an alternative form of economy, politics and ecology. Here, the developed economies must assume a role and a task of social-economic compensation for the colonization of peoples and cultures around the world, offering social rights and political powers to these marginalized peoples.

Tempo Brasileiro, 1984; MIGNOLO, Walter D. La idea de América latina: la herida colonial y la opción decolonial. Barcelona: Editorial Gedisa, 2007. 


\section{Modernization and Multiculturalism}

Contemporary philosophical-sociological theories, which assume modernity as the normative platform for epistemological-moral universalism and as a societal evolutionary stage of human development (in opposition to traditionalism) conceive of European modernity or Western modernization as a multiple evolutionary movement which takes its form from an intersection and imbrication between a process of cultural modernization and a process of social-economic modernization as a very dependent and correlated movement. This epistemological-political starting point of contemporary philosophical-sociological theories means that the emergence and development of modern European culture are concomitant to the emergence and development of capitalist economy and of the bureaucratic-administrative State. Therefore, modernity's self-understanding clearly becomes the modern path and direction: on the one hand, there are an institutional-secular culture and a strong notion of individuality that denies the traditional essentialist and naturalized foundations to social and individual lives; on the other hand, there are the capitalist market and the bureaucratic-administrative State as institutions shaped and streamlined by a self-referential, self-subsistent and autonomous logic and dynamic of functioning and programing-such systemic logics and dynamics are not normative or political, but technical, closed to social normativity and political praxis. Both processes-modern culture and modern economic-political institutions-are linked by a fundamental principle: a secular and individualistic modern culture, which leads to the end of the notion of society as a totality depending on normative grounding that embraces all institutions, individuals and social groups into a binding strong communal morality. Modern societies are individualized into particular institutions that centralize and monopolize the constitution and the evolution of specific social fields as their own fields. ${ }^{6}$

Such imbricated and dependent double process has very interesting characteristics which define also its powerful contradictions, namely that (a) modern European culture is a secular, individualistic and rationalized form of life and grounding; (b) it refuses essentialist and naturalized foundations to social-cultural life, to political praxis and to institutional evolution; (c) it is characterized by the end of a normative social totality very imbricated in its parts, that is, a modern society, contrarily to traditional societies, is differentiated in many social systems which are independent

\footnotetext{
${ }^{6}$ See HABERMAS, Jürgen. Teoria da ação comunicativa (Vol. I): racionalidade da ação e racionalização social. São Paulo: Martins Fontes, 2012a; GIDDENS, Anthony. Para além da esquerda e da direita: o futuro da política radical. São Paulo: Editora da UNESP, 1996; FORST, Rainer. Contextos da justiça: filosofia política para além de liberalismo e comunitarismo. São Paulo: Boitempo, 2010.
} 
and autonomous regarding moral foundations and political constitution; and (d) because of that, modern societies have concurring and irreconcilable principles of social integration and political orientation, as political power, money and social normativity. According to many contemporary philosophical-sociological theories based on the reconstruction of this notion of Western modernization, the modern emancipatory normative principles and the political-cultural practices emerge from here, as modernization's psychosocial pathologies. ${ }^{7}$ On the one hand, cultural modernity enables a decentered, universalistic and formalistic conscience that overcomes traditionalism's egoistic and ethnocentric cultural-political closure; on the other hand, modern capitalism and bureaucratic institutional politics have generated and consolidated not only an economic-social basis of production and political participation, but also a correlative individualistic, formalistic and secular consciousness which is the basis of economic-political activities and of cultural life as well. ${ }^{8}$

Such imbrication between cultural modernization (a universalistic culture and a formalist consciousness) and social-economic modernization (capitalism and the modern State) as a very dependent process and movement entails the direct association between human evolution and modernization, that is, the pure and simple equivalence of human evolution as cultural, social and economic modernization. Indeed, sociologically speaking, theories which assume Western modernization as their epistemological-political starting point (such as those of Karl Marx, Max Weber, Jürgen Habermas and Anthony Giddens) understand the specificities of modernity from a comparison and a contraposition between Western modernization and traditionalism. They start from the fact that Western modernization is a very specific and particular process of cultural, social and economic human evolution when compared to traditionalism. In other words, there are only two forms of societal life and constitution, namely traditional life and modern life. Here the first characteristic of sociological analyses of human evolution as a general process to mankind appears: looking at human history, it is possible to perceive that traditionalism is a basic platform from which all societies have developed and evolved over time, but, on the other hand, it is also possible to see that Western modernization breaks with this fundamental principle of human evolution, which is constituted by traditionalism. And Western modernization is a very particular process of human evolution because, as said above, in human history there are

\footnotetext{
${ }^{7}$ See HABERMAS, Jürgen. Teoria da ação comunicativa (Vol. I): racionalidade da ação e racionalização social. São Paulo: Martins Fontes, 2012a, p. 140-141; Idem, Teoria da ação comunicativa (Vol. II): sobre a crítica da razão funcionalista. São Paulo: Martins Fontes, 2012b. p. 278; GIDDENS, Anthony. A terceira via e seus críticos. Rio de Janeiro: Record, 2001, p. 13-42; Idem, A terceira via: reflexões sobre o impasse da social-democracia. Rio de Janeiro: Record, 2000, p. 122-123.

${ }^{8}$ HABERMAS, Jürgen. Ensayos políticos. Barcelona: Ediciones Península, 1997, p. 143-144.
} 
basically two forms of societal life and evolution-traditionalism and modernization. Now, what is Western modernization? It is exactly a process of overcoming traditionalism by a new form of human social-cultural constitution, legitimation and evolution - human evolution as modernization is the overcoming of traditionalism-Max Weber's notion of rationalization as European modernization's basic epistemological-cultural principle, assumed by Jürgen Habermas' theory of modernity, is a special example of this sociological understanding of European modernity's singularity and of the separation, in the history of human evolution as sociologically reconstructed, between modernization and all the rest as traditionalism. ${ }^{9}$

Philosophically speaking, modern culture, based on institutional secularism, on a strong notion of individuality and on a scientific and rational praxis, leads to a formalistic and universal consciousness that radically changes (according to the modern self-understanding) the way and the sense of the process of socialization and individualization. In modern society, there is no longer an imbrication between nature, society or culture and individuality, in the sense that society and its relationships are denaturalized, as the individual is separated from both nature and society, becoming an independent instance of the world. So, as a consequence, secular institutions, in the moment they become denaturalized, require a kind of normative-political foundation which is dependent on the intersubjective processes of deliberation, criticism and agreement by individuals and groups; likewise, modern individuality does not know other principle of foundation than itself, that is, modern individuality is the absolute normative-political principle to institutional-cultural foundation. From the correlation between secular institutions and strong individualism, which leads to the denaturalization of society and its normative-political grounding, emerges a universalistic and formalistic consciousness that fundamentally characterizes modern culture and individuality. Indeed, in modern societies, marked by pluralism, individualism and secularism, the metaphysical-theological arguments are put aside regarding the normative-political societal constitution, legitimation and evolution. Modern individuals and social-cultural groups must assume a rational conduct of life and a rational form of public argumentation which enable overcoming essentialist and naturalized normative principles and ways of foundation proper to traditionalism, substituting them with rational principles and ways of grounding. ${ }^{10}$

\footnotetext{
${ }^{9}$ See WEBER, Max. Ensayos sobre sociología de la religión (T. I). Madrid: Taurus, 1984; HABERMAS, Jürgen. Problemas de legitimación en el capitalismo tardio. Madrid: Ediciones Cátedra, 1999; Idem, Para a reconstrução do materialismo histórico. São Paulo: Brasiliense, 1990b; Idem, Teoria da ação comunicativa (Vol. I): racionalidade da ação e racionalização social. São Paulo: Martins Fontes, 2012a; Idem, HABERMAS, Jürgen. Teoria da ação comunicativa (Vol. II): sobre a crítica da razão funcionalista. São Paulo: Martins Fontes, 2012b.

${ }^{10}$ See HABERMAS, Jürgen. Teoria da ação comunicativa (Vol. I): racionalidade da ação e racionalização social. São Paulo: Martins Fontes, 2012a, p. 384-385.
} 
Here, as there are no more essentialist and naturalized principles and practices, public, equal and fair discussion between individuals and groups is the only path to the foundation of social normativity, since the best arguments and principles resulting from such process of public discussion and criticism are the objective socially biding arguments and practices. The modern way concerning normative-political foundation requires a new form of consciousness and a new epistemological basis when compared to the foundations and basis of traditionalism (again: according to the modern self-understanding, which takes its form from the opposition to traditionalism-modernity considers traditionalism as a less developed cultural form of life). If traditional societies can assume a naturalized and essentialist platform of principles and practices, modern criticism, based on secularism, individualism and scientism, denaturalizes the normative-political foundations, instituting in its place public dialog and formalist principles. Now, if traditional consciousness is naturalized, dependent on an essentialist notion of nature or on a theological revelation, modern consciousness has only an epistemological strategy in the age of pluralism, individualism and secularism: in order to reach public consensus and agreement by social interaction as the fundamental path of the normative-political foundation. How is such public consensus possible? Only by assuming formalist, impartial and neutral principles and practices from a procedural path and practice. In other words, modern individuals and groups, the moment in which an essentialist or naturalized foundation is delegitimized, can only ground socially binding norms and practices from a social interaction which is based on a non-egocentric and a non-ethnocentric conscience. A non-egocentric and non-ethnocentric conscience is the path to the foundation which is not compromised with a particular essentialist or naturalized principle and practice; it is streamlined by formalistic principles and practices that can assume a universalistic range and sense, that is, it is performed in the name of all, as it can be assumed by all: modern foundations and ways of grounding require that each individual and cultural group be able to put themselves in the place of other individuals and cultural groups (even if it means a strategic action). This is the epistemological-moral constitution of modernity's self-consciousness and culture.

Sociologically and philosophically speaking, Western modernization is the apex of human evolution-or its more developed stage-since it represents (and this is the modern self-understanding) the overcoming of traditionalism by a universalistic form of social-individual life and grounding. In this sense, modern culture and modern institutions (such as capitalism, State, rule of law and science) are totally linked and interdependent between themselves; thus, modern culture and consciousness cannot be understood without comprehending and linking them with modern institutions, since the globalization of cultural-economic modernization must be understood 
as an imbricated and mutually-supporting process of legitimation and evolution. This is what it means to say that modernization is a total process containing not only technical and logical systemic institutions (as liberal conservatism argues concerning the market structuration, legitimation and evolution), but also (and as a condition to that) a worldview that has an epistemological-normative paradigm from which institutional systemic evolution is legitimized and promoted. What does such connection between cultural modernization and economic modernization entail? It entails a double consequence: first, cultural modernization is the normative legitimation of economic modernization, and economic modernization is the empirical validation of that normative constitution represented by modern culture; second, such a correlative process entails a direct attack on traditionalism, naturalizing modernization itself (as culture and material form of societal life) by placing it as a mature human evolutionary stage. Therefore, modernization-both as culture and as economy-becomes the supreme normative-political and even technical criterion to criticize, integrate and intervene in all contexts, not only in the modernity itself.

Such normative context represented by Western modernization, as culture and as social form of life (individually and collectively), is the best place for the recognition of differences, as it is the best place in terms of social-economic development and in terms of political institutional constitution and legitimation. If traditionalism is characterized by an affirmation of only one form of life and by its dogmatic imposition to all (both in the very context of life and in terms of internationalism), Western modernization enables the correlation between multiple forms of life and an economic organization that supports many projects of life and forms of communalism (not only individualism and market competition). So, according to the philosophical-sociological theories based on the recovery and renewal of a normative-political notion of Western modernization (as proposed by Jürgen Habermas and Anthony Giddens), modernity becomes the very societal and normative paradigm from which criticism, integration and intervention regarding all contexts can be supported and legitimized, since, as said above, it has three important features: a universalistic culture, a democratic political institutionalism and a capitalist economy, allowing, in an imbricated way, the cultural-political integration of all differences and the material satisfaction of all human needs. In addition, it enables, as Habermas said, Europe to have today a second chance regarding the grounding and the performing both of an epistemological-moral universalism and of a cosmopolitan ethical-political project. ${ }^{11}$ So, what is the problem with contemporary modernization? In many ways, there is an increasing refusal of this universalistic culture by a very strong European-American chauvinism, as can be seen in the growth of social-economic inequalities

${ }^{11}$ See HABERMAS, Jürgen. La Constelación posnacional: ensayos políticos. Barcelona: Ediciones
Paidós, 2000, p. 10; Idem, O ocidente dividido. Rio de Janeiro: Tempo Brasileiro, 2006, p. 44-47. 
in the context of Western modernization (social-economic inequalities are no longer a problem only in underdeveloped countries). On the other hand, there is a very dramatic emergence of a form of colonialism as in the case of NATO and the Russian community, since the strong opposition between developed and underdeveloped economies cannot be forgotten, in the sense that developed economies create and maintain a relationship of dependence between center and peripheries over time characterized by the hegemony of the decentralization of industrial production and by the devaluation of the working classes, by the supremacy of financial capitals and the relaxing of the taxes and trade barriers, which contribute to deindustrialization and the poverty of underdeveloped countries. How is it possible in a universalistic culture and consciousness? Such questions lead us to perceive contradictions regarding the contemporary philosophical-sociological theories based on an idealized notion of Western modernization as the apex of human evolution, as the basic universal paradigm of criticism, intervention and integration.

\section{The Crisis of Western Modernization as Universal Cultural-Economic Paradigm}

It seems that the modern universalistic culture and the social-economic model of development based on capitalist economy cannot control economic destabilization, social poverty and political inequalities. In the view defended in this article, the reason for this is double and imbricated: (a) the correlation between modern culture and capitalist economic modernization is based on the naturalization of human evolution as modernization, leading, as a consequence, to the depoliticization of modernization - the understanding of economic modernization and of modern institutional political constitution from a systemic theoretical-political standpoint contributes to that; and (b) cultural-economic modernization as a more developed stage of human evolution becomes a totalizing, self-referential and self-supported paradigm and project of social integration, which leads not only to a direct contraposition to traditionalism, but also to the modern colonization of all societies and cultures, as to modern delegitimization of all alternative epistemologies, because they reject modernity's universalist epistemological-cultural self-understanding-on the other hand, modern universalism and economic modernization are processes in terms of epistemology, culture and economy which must assume both a universalist range and a permanent movement toward universalism, in a way that leads to the assimilation of all contexts into modern epistemological, cultural and economic rules and dynamics. As a higher stage of the human evolutionary process, cultural-economic modernization conceives of itself as the final stage which is concomitantly the starting point and the ending point 
to be achieved by the whole of mankind. Thus, the only alternative to a problematic modernization is more modernization, as our only alternative in terms of human cultural and societal evolution is again more modernization. In this sense, cultural-economic modernization as paradigm, cultural form of life and material economic organization must become the general context from which all symbols, practices and forms of life and production are legitimized, criticized and guided-modern epistemology, culture and economy become the normative umbrella from which all particular forms of life, production and normativity are assembled, oriented and judged by those who, from within modernity, and in the name of modernity, assume modern universalistic epistemology, culture and economy as the paradigmatic basis and societal project.

Now, the first important thing that must be understood about modern philosophical-sociological theories based on the normative reconstruction of a model of European cultural and economic modernity is the fact that modernization is conceived by them as a higher stage of human evolution, which overcomes traditionalism with a new, emancipatory and universalistic culture, epistemology and material form of life. Indeed, when we look at classical sociology (Comte, Marx, and Weber) and principally, in this case here, at contemporary philosophy and sociology (for example, Karl-Otto Apel, John Rawls, Jürgen Habermas, Anthony Giddens, Rainer Forst and even Axel Honneth), we perceive that the normative starting point of these authors is exactly the understanding that modern epistemology, culture, model of human being and material form of life are the same as those of modernization-and that modernization is a higher stage of human evolution, more mature than traditionalism. In other words, all these intellectuals adopt the modern paradigm as a normative basis to the construction of theoretical-political concepts and theorems. In the model of capitalist material production, it could be seen as a higher stage of human material and productive organization and development (Marx, Weber, Habermas, and Giddens) - Habermas said that capitalism has generated a universalistic form of culture and consciousness which is the normative starting point to universalism and to cosmopolitanism; ${ }^{12}$ it could be seen in the fact that rationalism or scientism is an epistemological paradigm superior to traditionalism (Comte, Apel, and Habermas); it could also be seen in relation to the philosophical assumption of moral-social psychology based on the idea that a mature kind of consciousness is characterized by the consolidation of a universalistic, formal, neutral and impartial model of thinking and moral action (Piaget, Kohlberg, Apel, Rawls, Habermas, Honneth, and Forst), founded on a non-egoistic and non-ethnocentric worldview (decentered moral consciousness, a post-conventional consciousness, in Piaget's and Kohlberg's words), which leads to the delegitimization of the traditional

\footnotetext{
${ }^{12}$ See HABERMAS, Jürgen. Ensayos políticos. Barcelona: Ediciones Península, 1997, p. 143-144.
} 
world as a model of culture and consciousness that is sufficient for life at large-modern European culture is the only one that has achieved a post-conventional constitution and evolution which differentiates it in relation to traditionalism. In contemporary philosophical-sociological theories, modernization is opposed again (as modern philosophy and classical sociology) to traditionalism, that is, there is only modernity as universalism and the rest of the world as traditionalism. There is universal modernity and particularized traditionalism: modernity as a form of society, culture and consciousness which separates culture, society and individuality, instituting rationalization as the normative-epistemological basis for grounding; on the other hand, traditionalism is marked by the strong imbrication between nature, society and individuality, with no internal rationalization, criticism and mobility. Now, the philosophical-sociological reading of the development of European modernity has shown that human evolution starts in traditionalism and becomes modernization as the direct and natural evolutionary pathway.

All this means the naturalization of epistemological, cultural and economic modernity. And what is the reason for that? The fact that human evolution is understood as a homogeneous and unitarSee y process which starts with traditionalism and achieves a universalistic form of epistemology, culture, and material production represented by European modernization. Here, universalism is the final stage of human evolution, not traditionalism. Now, the idea that human evolution leads to universalism means four important things which are fundamental to the construction of the contemporary philosophical-sociological theories that have Europe as their philosophical-sociological paradigm or normative background: first, traditionalism is a form of culture and consciousness very much attached to its own particular context; second, contrarily to that, modernity is a universalist form of life and consciousness due to its formalistic, impartial and procedural kind of moral thinking and of cultural constitution (institutional secularization and strong individualism); third, a traditional form of life and consciousness is egocentric and ethnocentric (i.e., attached to its own context), but the modern form of life and consciousness is non-egocentric and non-ethnocentric (i.e., universalistic, post-conventional); fourth, traditionalism is not rational and cannot enable a rational form of life and consciousness, but modernity is rational and allows a rational form of life and consciousness. Therefore, human evolution began as an egoistic and ethnocentric and became a universalistic (i.e., non-egocentric and non-ethnocentric) form of life. Human evolution started as a traditional and became a post-traditional or post-conventional form of life. This non-egocentric and non-ethnocentric form of life is the model of European modernity. ${ }^{13}$ It enables the affirmation (which is central to contemporary

${ }^{13}$ See HABERMAS, Jürgen. Teoria da ação comunicativa (Vol. I): racionalidade da ação e racionalização social. São Paulo: Martins Fontes, 2012a, p. 355. 
philosophical-sociological theories) that modernity as a mature stage of humanity (because it is a post-conventional one) can serve as a universalist and cosmopolitan epistemology, culture and economy.

The naturalization of Western cultural-economic modernization, therefore, signifies that the process of human evolution starts from traditionalism and myth and arrives at modern rationality, which means that human evolution begins as a closed, particular and fundamentalist form of life and consciousness and arrives at a universalistic, formalistic and procedural form of life and consciousness-modernization as a post-traditional world that overcomes and embraces the traditional world into its epistemology, culture and material and societal organization. Two important characteristics can be perceived in this modern self-understanding that determines both modern self-comprehension regarding its constitution, specificity and destiny and the modern comprehension concerning the rest of the world; in this last case, the relationship between, on the one hand, modernity and, on the other, traditionalism as a whole. First, the evolution of Western modernization appears, in the modern self-understanding, as a natural process and step, as the direct, positive and necessary overcoming of a closed and particular form of Seelife and consciousness by a universalistic, plural and decentered form of life and consciousness. Such naturalized condition of Western modernization depoliticizes both the modern self-understanding and the relationship between modernity and what is outside modernity. Second, as a consequence of the naturalization and depoliticization of Western modernization, there is the denaturalization and politicization of traditionalism as a form of life and consciousness, which is not right regarding human constitution, as with mankind's process of evolution. So, if traditionalism is not the present and the future of human evolution (both as culture and as epistemological-moral consciousness), it is not a normative paradigm from which all matters and processes can be framed, criticized and guided. Contrarily to that, the denaturalization and politicization of traditionalism, correlatively to the naturalization and depoliticization of Western modernization (by modern epistemological-cultural self-understanding) show two important things: traditionalism is unable to serve as universal normative paradigm from which criticism, intervention and integration are made possible-it is wrong in relation to the legitimation and orientation of a contemporary universalistic epistemological-moral paradigm and a cosmopolitan ethical-political project; then, only modernity can perform this task. In other words, due to its rationality and universalistic sense and range, Western modernization becomes the very central normative paradigm and societal organization from which all criticism, all intervention and all integration occur, as the ending point that must be achieved over time as a consequence of human evolution in overcoming traditionalism by the consolidation of a post-conventional society, culture and consciousness 
that is impartial, neutral, formal and procedural regarding ways of life and epistemological-political subjects.

Now, contemporary philosophical-sociological thinking in general is firmly based on such naturalization and depoliticization of modernity, which becomes the normative paradigm of all particular normative-political paradigms, as well as the societal basis par excellence of all particular and primitive societal organizations. In epistemological, ethical, political, cultural and economic contemporary discussions and proposals there is always the direct assumption of Western modernization as the starting point, but also as the final stage of human evolution in terms of epistemology, culture, politics and economy. It becomes the only alternative to our present, as it becomes our basic future, so that we cannot think outside it or without it. Could it be different? In other words, this is our vital world; modernity is our context, the context from which our problems, our questions and our possibilities are explicitly presented, so how can we think in another way? This is the point being argued here: the naturalization of Western modernization leads to its depoliticization, which means that our starting point and our final point are modernization itself; our fundamental paradigm is a naturalized and depoliticized modernization as our present and future, as our only paradigmatic, normative and ethical project. So, why do we need those who are outside modernity? For what do we need epistemologies, symbols, practices and voices that are outside the modern world? We do not need them, or at least we need them only if they are inside modernity, not against it. It is the moment when modernity becomes a colonizing epistemological, cultural and economic process based on the rhetoric of universalism as the condition to particularism. Besides, here appears the problematic self-association between modernity, rationality and universalism as an intrinsic and imbricated vital world and a universalistic epistemological-moral consciousness: from now on, Western modernization can correlatively embrace all vital contexts, delegitimizing epistemological and ethical alternatives, which means that modernity (a universal paradigm and form of life) becomes the fundamental normative paradigm and societal project from which all particular contexts gain sense and can be judged and guided. From now on, modernity does not allow criticism, intervention and integration, but the direct delegitimization of all alternative forms of life and values, becoming a naturalized and depoliticized totalizing process of colonization. From now on, therefore, criticism and intervention are possible only against all contexts which are outside modernity and by the use of modernity's normative paradigm and epistemological-political instruments, concepts, procedures and subjects. The naturalized and depoliticized modern critical sense and praxis are directed against those outside modernization - the traditional world's basic mistake is to stay outside modernity. But, from within modernization, criticism does not delegitimize the totalizing and colonizing movement 
towards the assimilation of all contexts into the modern rules, practices and material organization, because universalism is sense and the truth of traditionalism, for traditionalism-modern universalism as the normative umbrella for all contexts, for traditionalism at large. As a naturalized and depoliticized worldview, Western modernization, even if it has some problems, can correct itself, maintaining its universalistic sense and ran$\mathrm{ge}^{14}$ and its totalizing and colonizing movement toward universalism and cosmopolitanism, because it is the natural process of human evolution. The problem is not Western modernization, but those who are outside it. Such a paradigmatic starting point, as said above, delimits and defines contemporary philosophical-sociological theories that assume an idealized reconstruction of modern normativity as the condition of criticism, intervention and integration.

Let us resume the correlation between modernity and rationality, modernity as a rational form of life enabling a rational life and consciousness. Habermas's basic argument concerning the reconstruction both of the modern sociological evolution and of a normative or philosophical model of modern European culture is based on the presupposition that modern rationalism is a superior form of life and consciousness in comparison to traditionalism, as much as modern European culture is rational, enabling a rational form of life and consciousness, something that traditional societies cannot do from their internal principles and dynamics. ${ }^{15}$ According to Habermas, traditional societies are not rational nor enable a rational form of life and consciousness by the fact that they are organized and streamlined by myth and religion, in a fundamentalist way, which results in the very intrinsic link between nature, society and individuality. Such a profound link prevents the emergence of a process of institutional-cultural secularization and the consolidation of a strong notion of individuality. So, there are no social mobility and criticism in traditional societies, because their institutions are based on religion and myths, as there is not an individuality that is separated from nature and culture-individuals cannot criticize and break with their culture, with their institutions. Contrarily to that, European modernity is characterized by the separation of nature, society and individuality, based on institutional-cultural secularization and individualism, and this changes the way and the path of the epistemological-moral foundation. Here, in the modern world, norms and practices are only legitimate if they are constructed from an impartial, neutral and procedural kind of foundation with the presupposition of universality, as all peoples must participate equally and freely. Thus, only the authority of the best, that is, the most rational, argument is valid to ground modern

\footnotetext{
${ }^{14}$ See HABERMAS, Jürgen. Teoria da ação comunicativa (Vol. I): racionalidade da ação e racionalização social. São Paulo: Martins Fontes, 2012a., p. 227.

${ }^{15}$ Ibidem, p. 94-140.
} 
socially biding norms and practices. Now, modernity is a rational form of life and consciousness since it institutes only the communicative action or dialogical reason and the procedural paradigm as criteria to the foundation of norms and practices. As a consequence, modernity generates a rational form of life and consciousness because it leads its individuals and groups to assume a decentered, non-egoistic and non-ethnocentric form of life and consciousness, founded on rationalization. ${ }^{16}$

But why, from that understanding of the specific characteristics of European cultural modernity, does Habermas affirm rationalism both as a superior form of epistemological-moral consciousness in comparison to traditionalism and as enabling criticizing and framing the traditional epistemologies and cultures? Why, according to Habermas, is rationalism the normative umbrella to particular contexts, to the traditional world, not only to European modernity? Why is European modernity not only a particular form of life, culture and consciousness, but a universal one? First, by the fact that rationalism is, from an evolutionary point of view, the consequence of an improvement of mankind, the consequence of overcoming myth and religion as the bases of social and individual constitution. If Western modernity is the natural consequence of human evolution, then rationalism is its content, its epistemological-cultural content. Second, Habermas believes that all cultures have a similar structure of epistemological-moral justification, because all of them intend to objectively ground their socially biding norms and practices. Each particular culture searches for the strong objectivity of its internal rules and practices, performing a process of intersubjective education and justification based on the aim to inculcate this epistemological-moral objectivity as the condition to survival and reproduction of the native culture. ${ }^{17}$ Now, both characteristics of rationalism-it is Western modernity's epistemological-cultural content, and all cultures must rationalize their socially biding norms and practices-lead to Habermas's idea that a correct reconstruction of Western rationalism can enable the foundation of an epistemological-moral paradigm from which universalism is made possible as the fundamental principle and practice to human constitution and action over time, allowing the grounding of a universalistic epistemological-moral paradigm which conceives of the possibility of criticism, intervention and integration by a universalist paradigm which is impartial, neutral, and procedural: here emerges modernity's paradigm as universalism, as normative umbrella. If (a) rationalism is a higher stage of human evolution, if it is impartial, neutral and procedural (a decentered epistemological-moral consciousness, contrarily to a traditionalist centered epistemological-moral consciousness), and if (b) all cultures

\footnotetext{
${ }^{16}$ See HABERMAS, Jürgen. Direito e democracia: entre facticidade e validade (Vol. I). Rio de Janeiro: Tempo Brasileiro, 2003a., p. 20.

${ }^{17}$ See HABERMAS, Jürgen. Teoria da ação comunicativa (Vol. I): racionalidade da ação e racionalização social. São Paulo: Martins Fontes, 2012a, p. 326.
} 
have a similar structure of epistemological-moral justification that aims at the objectivity of their norms and practices, then modernity's normative paradigm based on rationalism can serve as a medium to an intercultural praxis, and to a critical, interventive and integrative universal paradigm as well, and not only inside modernity, but also outside of it-and from a modern epistemological-political praxis by modern subjects. ${ }^{18}$

Here we can see why modernity's normative paradigm conceives of itself both as the apex of human evolution and as a normative umbrella able to integrate and intermediate all cultures, symbols and practices, supporting and maintaining a critical approach regarding modernization itself, the traditional world itself and also the relationship between modernization and traditionalism. These characteristics of modernity lead to a modern self-comprehension based on the belief that modernity is both self-reflexive and sufficiently formalist, impartial and procedural to ground a universal epistemological-moral paradigm that can sustain the integration and the criticism of multiculturalism. In the first case, a self-reflexive modernity can always control its totalizing, colonizing and irrational tendencies, a quality of modernity's normative paradigm which legitimizes the continuation of its movement based on universalism and on the unceasing rationalization of all codes, practices and subjects; in the second case, as a universal epistemological-moral paradigm, modernity can integrate and intermediate all cultural forms of life both in one only normative paradigm and in a communal societal project of life. Therefore, modernity, according to contemporary philosophical-sociological theories, is both the normative paradigm and the societal organization that promotes multiculturalism, which is sensible to all differences - it is a self-reflexive epistemological-moral universalism, a self-reflexive and universalistic culture and a self-reflexive complex form of material production which supplies all that is needed.

However, such contemporary philosophical-sociological theories only can affirm modernity both as normative paradigm and as material societal project which is the basis for universalism and cosmopolitanism if they separate (as theoretical-political starting point and ending point) an idealized normative and romantic modern self-comprehension (its association with universalism, cosmopolitanism and the final stage of human evolution) and the Realpolitik of modernization, based on an epistemological, cultural and economic colonization. Here, some important characteristics that define modernity's self-comprehension and its relationship with the non-modern contexts can be perceived. The separation between modern normativity and the modern Realpolitik of colonialism implies the affirmation, by those philosophical-sociological theories mentioned above, that cultural modernity is self-reflexive in relation to the Realpolitik of social-economic modernization. It is both self-

${ }^{18}$ See HABERMAS, Jürgen. O discurso filosófico da modernidade: doze lições. São Paulo: Martins Fontes, 2002a, p. 8. 
-reflexive and independent regarding the Realpolitik of modern colonialism. Therefore, the first step to enables a reaffirmation of Western modernity as normative paradigm and societal project is the separation between modern normativity and the modern Realpolitik of colonialism, and this means the independence of the modern normative self-comprehension concerning the Realpolitik of colonialism. This independence means that cultural modernity is not guilty of the Realpolitik of colonialism; the separation between cultural modernity and the Realpolitik of colonialism entails that cultural modernity is self-reflexive to correct itself, to stop and to overcome modern colonialism from within and to legitimize the movement of modernity toward a universalist paradigm and a cosmopolitan societal project, integrating and intermediating all contexts into modern rules, practices and epistemology. The second step of contemporary philosophical-sociological theories is the direct association (based on a romanticized self-comprehension) between European modernity, universalism and rationalism, as their understanding that such association is mankind's evolutionary route, meaning that overcoming traditionalism and consolidating a decentered culture and form of life. Here, rationalism becomes the result of human evolution and the paradigmatic basis to intermediate an intercultural dialog and praxis. This second step means that rationalism is the normative criterion from which all cultures can be evaluated, criticized, intervened in and integrated into a universal normative paradigm and into a cosmopolitan ethical-political project. Previously, if multiculturalism is possible, it is only inside modernity and by modernity; it is possible by modern rules and practices, by its localization within the context of modernity. In other words, multiculturalism is only promoted from a process of permanent modernization and modern epistemological, cultural, political and even economic assimilation. This is our contemporary theoretical-political problem: the naturalization and depoliticization of Western modernization, which lead to a philosophical-sociological blindness regarding both the profound link between cultural modernity and economic modernization, and to the association of modernity, universalism and human evolution, as well as to the association between modernization and emancipation. ${ }^{19}$

\section{Duty of Reparation for Colonialism as a New Politics for Modernity: To a Renewal of Modernity's Paradigm}

Indeed, as presented above, the association between Western modernization, universalism and human evolution leads to the naturalization of Western modernization, since it is a result of a process of social, cultural and moral evolution which overcomes traditionalism as a partial form of thinking and

${ }^{19}$ See HABERMAS, Jürgen. Teoria da ação comunicativa (Vol. I): racionalidade da ação e racionalização social. São Paulo: Martins Fontes, 2012a, p. 146-148. 
life, becoming modernity itself, which is a full form of life and a mature or universalistic epistemological-moral culture and consciousness. It can be perceived that, in modern and contemporary philosophical-sociological theories, modernity as a final stage of human evolution is not a random process, as if human evolution had other possibilities and pathways. Contrarily to that, modernity is both a direct pathway of human evolution and a cultural construction under the shadow of traditionalism: it is in this sense that Western modernization, as a normative paradigm, culture and material and societal organization, is the apex of human evolution and a universalistic normative paradigm, culture and material and societal organization that can embrace, assemble and integrate all normative paradigms, forms of life and culture and forms of material production as well. Therefore, in this idealized and normative modern self-comprehension, human evolution is a progressive work that leads, by laborious, patient and painful human action against itself, against nature, to modernity as a direct and natural evolutionary pathway. This is the meaning of Western modernity's universalism: as a mature stage of human evolution, it has a more abstract and generic range and constitution, which can assume from the inside to the outside both the particular contexts and the normative guidance and legitimation of all that is now within modernity and dependent on modernity - there is nothing outside modernity, actually, because, as the apex of human evolution, modernity becomes the final stage that assumes, from inside, all forms of life, culture and thinking. Human evolution is a process of consolidation of universalism and cosmopolitanism, and modernity means universalism and cosmopolitanism, becoming, as a consequence, the normative paradigm and the material and societal project from which all peoples, cultures, epistemologies and morals acquire meaning and can be guided.

So, the philosophical-sociological theories based on the affirmation of modernity's normative and material paradigm suffer from a philosophical-sociological blindness founded on the separation between an idealized comprehension of cultural modernity and the Realpolitik of modern colonialism. Their first step is exactly to assume that Western modernization or European modernization is the final stage of human evolution, as a universalistic and cosmopolitan paradigm, culture and material form of life, which is superior to traditionalism - a form of epistemology, culture and material organization that overcomes traditionalism. Their second step in the affirmation of modernity's normative paradigm is to assume that it is synonymous with universalism and cosmopolitanism, that is, that modern rationalism leads to universalism and cosmopolitanism, which means that human evolution starts from traditionalism and ends with rationalism as a higher level of human evolution as a whole. Their third step is to conceive of human evolution as a unitary process, as the process of mankind - mankind as universal, cosmopolitan, rational, modern. At this 
point, the philosophical-sociological blindness leads us into not associating directly epistemological-moral universalism and the Realpolitik of modern colonialism, since they are not interdependent. Actually, modern normative culture is self-reflexive with regard to modern colonialism, as it is the modern instrument to an internal self-correction of modernity and by modernity itself, which leads to the reaffirmation of its universalistic and cosmopolitan vocation, sense and range: it is the normative paradigm and the material and societal project from which to start in terms of grounding, framing and guiding.

That is the very context of contemporary multiculturalism, that Western modernization offers a universalist epistemological-moral paradigm in which all cultures and forms of life can be embraced, assembled and guided, since it is the material and societal structure (in terms of capitalism, industrialism, consumerism, etc.) from which all peoples can have a fair and effective integration. In other words, modern epistemology, based on rationalism and modern material and societal structuration, based on capitalism, becomes the common principle and the fundamental groundwork from which universalism and cosmopolitanism are possible, which means that modernization is the real political form of multiculturalism. Only within modernity and by a process of modernization, only assuming modern epistemology and decentered culture, multiculturalism is possible to be experienced, promoted and fomented over time. This entails, as is being argued in this article, the naturalization and depoliticization of Western modernity both as normative paradigm and as a material societal organization. The objective now is to argue that such a philosophical-sociological blindness regarding the use of modernity's normative paradigm is the great contemporary problem both for the correction of modernity's pathologies and for the precarious relationship between modernity and what is outside modernity. Firstly, contemporary philosophical-sociological theories based on modernity's normative paradigm, despite their good intentions, cannot serve as self-reflexive epistemological-political standpoint to the internal control of the colonizing and totalizing tendency of Western cultural-economic modernization. The reason is that they separate, on the one hand, a normative and idealized understanding of Western modernization and, on the other hand, the Realpolitik of modernization, which is a colonizing and totalizing process, both internal and external to modernity, in relation to other contexts. Such a separation covers, obscures, erases and delegitimizes the dependence between that normative comprehension of European cultural modernity and the Realpolitik of colonialism, naturalizing and depoliticizing modernization. So, as a consequence, modernity becomes the fundamental paradigm from which any criticism, intervention and integration are legitimized and made possible. No criticism of Western modernization can delegitimize the fact that European cultural modernity is a universal culture, consciousness and paradigm separated from social- 
-economic modernization, which means that cultural modernity is always purified from the sins and irrationalities of Western modernization: these sins and irrationalities are caused by social-economic modernization, not by cultural modernity, which leads to the fact that cultural modernity maintains its self-reflexivity, its capability of internal self-correction and, as a consequence, its universalistic sense and range, becoming the normative paradigm of all particularized normative paradigms. ${ }^{20}$

Secondly, it is a fact that modern colonialism has used and continues to use modernity's normative paradigm to justify its interventive and integrative project of globalization. It could be argued that modern normativity does not allow such use of it, but, if we remember the normative notion of cultural modernity reconstructed above, we will perceive that modernity's very movement is exactly directed toward universalism and cosmopolitanism, from the contraposition between modernity and traditionalism, from the contraposition between rationality and fundamentalism, from the affirmation that Western modernization is a universal form of society, culture, consciousness and paradigm in relation to traditionalism. Then, human evolution is a process of modernization, rationalization and universalism, not a process of traditionalism and fundamentalism. The modern crusade in favor of universalism and cosmopolitanism naturalizes and depoliticizes both modernity's normative self-comprehension and the political use of its normative paradigm to frame and intervene in other contexts. As a consequence, modernity's normative paradigm remains unquestioned and untouched by a critical social theory, which, as much as a liberal political praxis, uses it to ground a notion of universalism and cosmopolitanism as the basis to understanding a notion of social normativity that also serves international politics and cultural-economic globalization. Contemporary colonialism, in attacking everything that is outside globalized liberal capitalism, uses modernity's normative paradigm to delegitimize and politicize others' tyranny, fundamentalism, barbarism, and violence. As was said above, modernity's normative paradigm cannot control this situation due to the fact that it naturalizes and depoliticizes cultural-economic modernization, by conceiving of it as the final stage of human evolution and as a rational form of life, culture and material production. It leads to the denaturalization and politicization of all that is outside modernity, legitimizing the pursuit of modernity into universalism and cosmopolitanism, the consolidation of universalism and cosmopolitanism as cultural-economic modernization, as a complete rationalization of all contexts, cultures and forms of life. This cannot be controlled from within modernity's self-reflexive paradigm, because it is not a self-reflexive normative standpoint regarding itself, regarding Western modernization

\footnotetext{
${ }^{20}$ See HABERMAS, Jürgen. Teoria da ação comunicativa (Vol. I): racionalidade da ação e racionalização social, p. 355; FORST, Rainer. Contextos da justiça: filosofia política para além de liberalismo e comunitarismo. São Paulo: Boitempo, 2010, p.8, p. 196-210.
} 
as a universal form of society, culture, consciousness and paradigm, but a naturalized and depoliticized paradigm based on the totalizing and unstoppable universalistic rationalization which is universal only by the delegitimization and assimilation of all that is not rational in modern terms. In the same sense, modernity's normative paradigm becomes naturalized and depoliticized by assuming itself as a universal paradigm, which means that its criticism can only be performed and streamlined by modernity's normative paradigm itself or by the assumption of modern epistemology as the condition of such criticism. Therefore, only by becoming modern can we criticize Western modernization, but, on the other hand, we can criticize all that is outside modernity by being modern epistemological-political subjects, because universalism is provided by modernity. Universalism belongs to modernity's normative paradigm and to modern epistemological-political subjects.

Western modernization or European modernization is basically an epistemological, political, cultural and economic construction, not a natural process of human evolution. As a consequence, it cannot serve as a universalistic epistemological-moral paradigm of criticism, intervention and integration and as a cosmopolitan project of social-political integration. Ultimately, it cannot offer, contrarily to what Habermas, Rawls and Forst believe, the procedural paradigm from which norms and practices to a multicultural world can be constructed and legitimized. So what can be done? First, such philosophical-sociological blindness and romanticization of modernity's normative paradigm can be denounced and deconstructed, showing the profound and intrinsic link between modern normative self-comprehension and the Realpolitik of modern colonialism, which is very important to understand both the contemporary philosophical-sociological theories, which start from modernity's naturalized and depoliticized normative paradigm, and the current Realpolitik of liberal capitalism. Such observations show that cultural-economic modernization as globalization is not possible as the general normative paradigm and material context from which all societies can be peacefully integrated and from which all human needs can be integrally met. There is an intrinsic connection between modernity's normative paradigm and the Realpolitik of contemporary cultural-economic modernization, which means that our current big problem is this modern totalizing movement toward globalization, in a way that modernity's normative paradigm becomes the normative umbrella for all particularized normative paradigms, embracing all societies, cultures and epistemologies into the model of Western modernization as a whole, so that Western modernization assumes the role of judge and guide-an untouched and uncritical role of judging and guiding self-attributed by modernity by assuming itself as a universal society, culture, consciousness and paradigm as the final stage of human evolution as overcoming traditionalism. 
Second, and as a consequence, we can speak about the self-limitation of modernity from within as the effective normative-political praxis which gains sense from the perception of that philosophical-sociological blindness found in the naturalization and depoliticization of modernity's normative paradigm. Modernity is not a universalist paradigm, culture and material and societal organization, then it cannot assume a universalist sense, range and movement. What remains to a critical social theory is exactly the radical contraposition to universalism, to cosmopolitanism and to cultural-economic globalization as the fundamental task and praxis to the heirs of modernity as modernity's heritage. Such an opposition to universalism and cosmopolitanism is not a bad thing: It is the recognition that the legacy of modernity insofar as correlation between modernization, rationalization, universalism and human evolution is a normative-political fantasy created to justify colonialism and/or to affirm a separation between modernity and non-modernity that legitimizes not only the specificity and singularity of modernity in relation to the rest of the world, but also the civilizing and educational vocation, task and guidance of modernity. Of course, modernity's normative paradigm is important to the understanding of the internal context of modernization itself, but it cannot be used to understand, frame and organize all that is outside modernity. This is the normative-political movement which is forbidden to modernity. Contemporary philosophical-sociological theories, as the current Realpolitik of colonialism, use modernity's normative paradigm as a naturalized and depoliticized basis to understanding and framing all contexts, cultural forms of life and political regimes, which is a mistake.

Third, the self-limitation of modernity from within as modernity's heritage and task, contrarily to Habermas's and Forst's defense of a renewal of modernity's normative paradigm as universal and cosmopolitan, means a radical normative-political criticism against the self-supported cultural modernization and economic modernization. Here we can situate modernity's self-restraint as an anti-colonial praxis based on the duty of reparation for colonialism. Such reparation for colonialism, as an anti-colonial praxis, leads to three epistemological-political actions which constitute, in my view, modernity's agenda to the $21^{\text {st }}$ century: (a) the deconstruction of modern epistemology based on the association between rationalism and universalism as the refusal of the idea that rationalism is a higher form of epistemological-moral consciousness than traditionalism and fundamentalism; (b) the refusal of the naturalization and depoliticization of the culture of modernity as the apex of human evolution, as a consequence of human evolution, which means the correlative refusal of the idea that modernity can embrace, assemble and guide all particular forms of life and culture and all epistemologies; (c) an economic reparation for world poverty and for social inequalities, which means the limitation and the radical control of liberal capitalism, redefining also the unstoppable industrialism, the immoderate 
consumerism and the ecological destruction. Above all, the perception of an intrinsic link between modernity's normative self-comprehension and the Realpolitik of modern colonialism implies that Western modernity, contrarily to what Habermas believes, cannot perform at the same time a self-reflexive praxis from within and continue with its totalizing movement towards universalism and cosmopolitanism, turning such universalism and cosmopolitanism into modernization, the final task for modernity itself $-\mathrm{a}$ task that must be performed by modernity from a contraposition to traditionalism. In other words, epistemological and cultural-economic colonialism walk together, they cannot be separated. That is the starting point and the final point of a new approach to epistemological, cultural and economic Western modernization, as the reparation for colonialism intends to show to the theories of modernity in order to unveil, denounce and change their historical-sociological blindness.

\section{Conclusion}

As a conclusion, I want to reinforce some important points about the problem of contemporary theories of modernity and, afterwards, about of the proposed idea of reparation for Western colonialism as a normative concept that unveils, criticizes and even changes the historical-sociological blindness of contemporary theories of modernity regarding the understanding of the process of Western modernization as a whole. First of all, I repeat, the historical-sociological blindness of contemporary theories of modernity (as those of Weber, Habermas, Forst etc.) is characterized by the differentiation between European cultural modernity and social-economic modernization - a dual understanding of the process of Western modernization-, which become non-correlated and non-mutually supported moments of a complete evolutionary human, institutional, cultural and paradigmatic process. By such separation, the theories of modernity can purify European cultural modernity of any risk of irrationality and pathologies; on the other hand, and as a consequence, social-economic modernization becomes the only instance to be blamed for the sins, irrationalities and pathologies of Western modernization. Likewise, cultural modernity, by its independence and pure normative constitution, can control, frame and guide the critical theoretical analysis and the emancipatory political praxis regarding the pathologies of social-economic modernization, so that cultural modernity, by its independence and separation in relation to social-economic modernization, allows the self-criticism and the self-correction of Western modernization itself from within, maintaining the claim of cultural modernity as a universal society, culture, consciousness and paradigm. 
The second important consequence of this historical-sociological blindness of contemporary theories of modernity is the association between modernization, rationalization, post-conventionalism, universalism and human evolution, so that modernization becomes the apex of human evolution. Indeed, Habermas and Forst argue that human evolution leads to universalism and, as a consequence, that European cultural modernity is the first form of society, culture, and consciousness to allow the development of a universal paradigm characterized by an impartial, neutral and formal proceduralism that can serve as a normative umbrella for all particularized societies, cultures and paradigms - only European cultural modernity has reached an effective universalism as a formal, impartial and neutral proceduralism, as a non-egocentric and non-ethnocentric culture, consciousness, and paradigm. In other words, modernity's normative paradigm as the apex of human evolution, as pure universalism, enables social criticism and political praxis of a plural world, for a plural world-that is the aim of the theories of modernity in terms of renewal and reconstruction of modernity's normative paradigm from communicative reason, from the separation between cultural modernity and social-economic modernization, as well as from the direct association between modernity and universalism, modernity as the ending point of human evolution. Now, such a historical-sociological blindness found in contemporary theories of modernity naturalizes and depoliticizes Western modernization as a whole, both by that separation and by the association between modernization, rationalization, universalism and human evolution. As a consequence, no social criticism can delegitimize modernity's normative paradigm; furthermore, if social criticism and an emancipatory political praxis are to be performed both inside and outside modernity, then modernity's normative paradigm must be used in its basic principles and procedures, as we must become modern epistemological-political subjects. In other words, we cannot leave modernity if a critical theoretical analysis and an emancipatory political praxis about modernity and regarding what is outside modernity is to be performed. This is modernity's naturalized and depoliticized normative paradigm as a consequence of the historical-sociological blindness found in contemporary theories of modernity.

It is from here that the concept of reparation for Western colonialism can serve as an epistemological-political basis for a critical social theory that is more effective than the concept of cultural modernity. Indeed, it basically allows the unveiling, denouncing and criticism of the historical-sociological blindness assumed by contemporary theories of modernity in order to save a universalistic concept of European cultural modernity, which leads to the naturalization and depoliticization of modernity's normative paradigm. Now, the normative-sociological concept of reparation for Western colonialism enables linking cultural modernity, social-economic modernization and the phenomenon of colonialism, showing that there 
is an intrinsic connection and dependence between these three moments which cannot be erased or deleted, as attempted by contemporary theories of modernity. As a consequence of that link, of the mutual dependence and support between cultural modernity, social-economic modernization and colonialism, the normative concept of reparation for colonialism can ground a very acute critical social theory and an emancipatory political praxis for modernity itself and for international politics. The reason is that the naturalization and the depoliticization of modernity's normative paradigm (the association and dependence between modernization, rationalization, universalism and human evolution) conceals and at last effaces the totalizing movement toward universalism and globalism assumed by Western modernization as a whole, as the imbrication between cultural modernity, social-economic modernization and colonialism, something that the reparation for Western colonialism shows from the beginning by opposing the historical-sociological blindness of contemporary theories of modernity.

The concept of reparation for Western colonialism denaturalizes and politicizes the process of Western modernization and, as a consequence, denaturalizes and politicizes modernity's normative paradigm and its association between modernization, rationalization, universalism and human evolution. From now on, Western modernization is a very unified totality and movement which congregates normative justifications (cultural modernity) with a material-institutional process of constitution, development and evolution having as basic characteristic the totalizing movement toward the assimilation of all contexts, subjects and epistemologies into the normative, institutional and societal umbrella constituted by Western modernization as a whole. From now on, the most important and urgent theoretical-political task for a critical social theory and for an emancipatory political praxis is the self-restraint of the process of Western modernization from within, by modernity's sons and modernity's bastards (the fruits of Western colonialism) in order to limit and to cease modernity's totalizing movement of assimilation of all societies, peoples, cultures and epistemologies in one same economic, institutional and paradigmatic basis constituted by Western liberal capitalism. In this sense, the self-restraint of the process of Western modernization and of modernity's normative paradigm could signify two imbricated moments: first, the reparation for colonialism, in the sense that global politics would assume the task of minimizing and eliminating social-cultural inequalities, poverty and militarism, as well as all forms of violence that are based on the totalizing globalism of modernity's normative paradigm, on the pursuit of the process of Western modernization; second, it is possible to correct the internal pathologies of Western modernization by assuming the link between cultural modernity and social-economic modernization, which means that modern social systems (that cause modern psychosocial pathologies-modern State and 
capitalist market) are normative-political, and not merely technical-logical structures. Now, as normative-political structures, they can be framed, criticized and changed by a critical social theory and from an emancipatory political praxis directed to the understanding and correction of the process of Western modernization.

Indeed, one more observation is important about this last case. In contemporary theories of modernity, the historical-sociological blindness adopted by them in order to save a normative concept of cultural modernity as epistemological-moral universalism leads to the fact that cultural modernity is a pure normative sphere (lifeworld), while social-economic modernization is characterized fundamentally by technical-logical or instrumental social systems (modern bureaucratic-administrative State and capitalist market). Now, such a firm separation between normative cultural modernity and technical-logical social-economic modernization means that each one of these fields is totally different regarding the other, so that a normative-political praxis cannot directly intervene in a technical-logical sphere, as normative-political practices, principles and subjects (which are proper to cultural modernity) cannot directly replace technical-logical practices, principles and subjects (which are proper to modern social systems). That is the reason why Habermas says that a direct political-normative praxis regarding modern social systems is not possible, but only an indirect interventionist politics (see Habermas, 2003b, p. 147-148). ${ }^{21}$ In this sense, a radical political democracy for a contemporary democratic society based on the process of Western modernization is an indirect political praxis concerning the pathologic social systems. A direct democratic political praxis regarding them is not possible for contemporary political subjects, because of this separation between a pure normative cultural modernity and the pure technical-logical modern social systems. Now, the concept of reparation for Western colonialism, the moment it links cultural modernity, social-economic modernization and colonialism, overcoming the historical-sociological blindness adopted by the contemporary theories of modernity, shows firstly that there is no separation between the pure normative cultural modernity and the pure technical-logical social systems; secondly, that modern social systems are normative-political institutions with normative-political principles, practices and subjects. As a consequence, the concept of reparation for Western colonialism leads to the legitimation of a direct normative-political praxis into social systems as the only basis for understanding, framing and changing their pathologies and irrationalities. For example, in this sense, political participation and economic reformulations must acquire a normative-political sense, and not a technical-logical one centralized in and monopolized by political parties,

\footnotetext{
${ }^{21}$ See HABERMAS, Jürgen. Direito e democracia: entre facticidade e validade (Vol. II). Rio de Janeiro: Tempo Brasileiro, 2003b, p. 147-148.
} 
economic elites and scientific-technical staffs. Therefore, political and economic institutions must be submitted to a normative-political democratic praxis as the only epistemological-political instance for the constitution, legitimation and evolution of social systems.

\section{References}

BENAYON, Adriano. Globalização versus desenvolvimento. Brasília: LGE, 1998.

BOLTANSKI, Luc \& CHIAPELLO, Ève. O novo espírito do capitalismo. São Paulo: Martins Fontes, 2009.

FORST, Rainer. Contextos da justiça: filosofia política para além de liberalismo e comunitarismo. São Paulo: Boitempo, 2010.

GIDDENS, Anthony. Para além da esquerda e da direita: o futuro da política radical. São Paulo: Editora da UNESP, 1996.

GIDDENS, Anthony. A terceira via: reflexões sobre o impasse da social-democracia. Rio de Janeiro: Record, 2000.

GIDDENS. A terceira via e seus críticos. Rio de Janeiro: Record, 2001.

HABERMAS, Jürgen. Pensamento pós-metafísico: estudos filosóficos. Rio de Janeiro: Tempo Brasileiro, 1990a.

HABERMAS, Jürgen. Para a reconstrução do materialismo histórico. São Paulo: Brasiliense, 1990b.

HABERMAS, Jürgen. Ensayos políticos. Barcelona: Ediciones Península, 1997.

HABERMAS, Jürgen. Problemas de legitimación en el capitalismo tardio. Madrid: Ediciones Cátedra, 1999.

HABERMAS, Jürgen. La Constelación posnacional: ensayos políticos. Barcelona: Ediciones Paidós, 2000.

HABERMAS, Jürgen. Comentários à ética do discurso. Lisboa: Instituto Piaget, 2001.

HABERMAS, Jürgen. O discurso filosófico da modernidade: doze lições. São Paulo: Martins Fontes, 2002a.

HABERMAS, Jürgen. A inclusão do outro: estudos de teoria política. São Paulo: Loyola, 2002b.

HABERMAS, Jürgen. Direito e democracia: entre facticidade e validade (Vol. I). Rio de Janeiro: Tempo Brasileiro, 2003a.

HABERMAS, Jürgen. Direito e democracia: entre facticidade e validade (Vol. II). Rio de Janeiro: Tempo Brasileiro, 2003b.

HABERMAS, Jürgen. O ocidente dividido. Rio de Janeiro: Tempo Brasileiro, 2006.

HABERMAS, Jürgen. Europe: the faltering project. Cambridge: Polity Press, 2009. 
HABERMAS, Jürgen. Teoria da ação comunicativa (Vol. I): racionalidade da ação e racionalização social. São Paulo: Martins Fontes, 2012a.

HABERMAS, Jürgen. Teoria da ação comunicativa (Vol. II): sobre a crítica da razão funcionalista. São Paulo: Martins Fontes, 2012b.

HARTMANN, Martin; HONNETH, Axel. “Paradojas del capitalismo", p. 389-422. In: HONNETH, Axel. Crítica del agravio moral: patologías de la sociedad contemporánea. Buenos Aires: Fondo de Cultura Económica, 2009.

HONNETH, Axel. Luta por reconhecimento: a gramática moral dos conflitos sociais. São Paulo: Editora 34, 2003.

MIGNOLO, Walter D. La idea de América latina: la herida colonial y la opción decolonial. Barcelona: Editorial Gedisa, 2007.

OFFE, Claus. Problemas estruturais do Estado capitalista. Rio de Janeiro: Tempo Brasileiro, 1984.

OFFE, Claus. Capitalismo desorganizado: transformações contemporâneas do trabalho e da política. São Paulo: Brasiliense, 1994.

PIKETTY, Thomas. O capital no século XXI. Rio de Janeiro: Intrínseca, 2014.

RAWLS, John. O Liberalismo político. Brasília: Instituto Teotônio Vilela; São Paulo: Editora Ática, 2002.

WEBER, Max. Ensayos sobre sociología de la religión (T. I). Madrid: Taurus, 1984.

Endereço do Autor:

Departamento de Filosofia - Campus José Ribeiro Filho

Universidade Federal de Rondônia

BR 364, KM 9,5 - Zona Rural

76.801-059 Porto Velho - RO

leno_danner@yahoo.com.br 